\title{
Post-Electoral Democracy: A Proposal for Expanded Political Subjectivity
}

\author{
Daniel Innerarity \\ University of the Basque Country/Ikerbasque Foundation for Science, Saint Sebastian/Donostia, Spain \\ Email: dinner@ikerbasque.org
}

How to cite this paper: Innerarity, D. (2018). Post-Electoral Democracy: A Proposal for Expanded Political Subjectivity. Open Journal of Political Science, 8, 206-225. https://doi.org/10.4236/ojps.2018.82015

Received: March 26, 2018

Accepted: April 25, 2018

Published: April 28, 2018

Copyright $\odot 2018$ by author and Scientific Research Publishing Inc. This work is licensed under the Creative Commons Attribution International License (CC BY 4.0).

http://creativecommons.org/licenses/by/4.0/

\section{(c) (i) Open Access}

\begin{abstract}
In an interdependent world, this sensation that not everyone who should be here is here, that our constituencies should be completed with other criteria of inclusion, that there may be some who have been illegitimately excluded from our group points to a triple inclusion-spatial, temporal and natural-that we should undertake: the inclusion of our neighbors, of our descendants and of the environment. None of these three "votes" enough. One of the principal challenges of contemporary democracies is how to reintroduce these subjects in our systems of representation and decision-making. If this hypothesis is correct, then we have a true democratic deficit and the habitual question about whether democracy is possible beyond the national state should be reformulated to ask instead whether democracy is possible without including those who are outside the national state, or more concretely, whether we can continue calling a political system a democracy if it does not internalize the interests of its contemporaries, does not anticipate the rights of future generations or does not recognize in some way the political subjectivity of nature.
\end{abstract}

\section{Keywords}

Constituencies, Transnational Democracy, Intergenerational Democracy, Ecological Democracy

\section{Introduction}

The building of constituencies-from the census of those who have the right to vote-is, as Montesquieu pointed out, one of the principal requirements for modern democracies. Establishing who votes, at what moments and under what circumstances has been one of the central issues of political discussions (Colomer, 2001). Through the establishment of electoral districts, individuals are represented by virtue of belonging to a particular territory. These territorial lim- 
its are essential to determine the area of competition, the comprehensiveness of representation, the range of control of power and accountability. One of the principal achievements of democracy continues to be manifested in the right to vote, as census suffrage was replaced by universal suffrage and women were granted the right to vote. Nowadays, the universalization of the right to vote has been so complete that it would seem senseless to wonder whether there is anyone else who still needs to be granted that prerogative.

However, the concern about whether our social practices are sufficiently inclusive and about whether anyone is illegitimately excluded from the right to participate, through the vote or other procedures, is a genuinely democratic concern. It is possible that universal suffrage exhausted the subjectivity that could exist in a world configured into states, which is no longer our world, and that there is still someone who, literally and metaphorically, cannot vote but should be able to do so.

Electoral representation does not allow for the taking of responsibility for problems that cross borders or that are distant in time, nor problems related to the environment; these matters demand another type of democracy, one which I will call post-electoral democracy, but we could also talk about an extension of parliamentarism, of inclusive democracy, transdemocracy, interdemocracy or ecological democracy.

\section{An Insufficiently Representative Democracy}

I begin with the observation that we have a crisis of representation (which is broadly shared), but we are not in strict agreement about its nature and the steps needed to overcome it. From the point of view of political subjectivity, the dilemma we face is whether the number of people who intervene in decision-making processes is too great (this would lead to the revindication of national sovereignty) or too small (an idea bemoaned by those who would like to move toward a post-national or cosmopolitan democracy). From the point of view of decision-making, the two options are between those who believe that elections are too much (Brennan, 2016; Achen \& Bartels 2016) and those who think they are too little (Norris, 2015; van Reybroucke, 2016) when it comes to identifying and asserting the popular will. Some people are only concerned about collective errors, and others about the fact that decisions are not truly collective. Some insist on reminding us of voters' mistakes, and others emphasize the limitations of electoral processes when it comes to determining and asserting the popular will. For the first group, elections represent what voters want all too well and, for others, not well enough.

The identification of democratic insufficiency that I am proposing focuses on something different. When one thinks that voting is too much or too little, one is assuming that those who should vote are voting and perhaps the most important question is not how they do it but who does it. My alternative hypothesis is that there are, in our procedures of representation and decision-making, less sub- 
jects, interests and values than there should be, which could mean that our constituencies are incomplete. It is not that we vote or participate little, but that those of us for whom that right is recognized are few. We must add the subjects of democracy that are missing, going beyond existing constituencies if we want democracy under the world's new conditions to achieve the principle of self-government that has always inspired it. "We" are the subject of democracy, but it may be that this subject is not yet fully contained within the list of those who have the right to vote.

All modern democracies have chosen a type of territorial regrouping. The idea of democracy is connected to the census, as has to be the case, but it is worth questioning whether all forms of legitimacy are exhausted in this way, whether we represent in this way all that must be represented, whether there are other forms of legitimacy that we could call implicit or hypothetical, through which we recognize the category of political subjects who can only indirectly approve decisions that are adopted or cannot approve them at all. Human rights transcend borders; they do not define them, but with democracy, it is just the opposite (Smith, 2003: p. 158). Democracy is encapsulated in the realm in which it emerged and in which we presume it is viable, but the question we should ask ourselves would not be about whether it is possible to transcend those limits but whether it is true that remaining on this side of them betrays democracy in some fashion. This leads us to consider other democratic deficits of which we are less aware than the ones that stem from not sufficiently recognizing the rights of the electorate: that the electorate itself is insufficient. In the end, this forces us to consider a democracy that is more deliberative than expressly representative or participatory.

Modern democratic theory has been obsessed with rejecting the arbitrary delimitation of subjects whose interests are worthy of political consideration. It is from this perspective, then, that I propose that we take seriously the new constituencies that have sprung up with the reality of interdependence and the ecological question: the inhabitants of other countries, future generations, non-human species. Cross-border self-determination, the rights of future generations and the politics of nature are the three principal issues that our democracies should address if we want to include everyone who should be included in our processes of representation and decision-making. Our democracies should be opened to additional contemporaries, to future generations and to ecological environments. Cross-border democracy, intergenerational democracy and ecological democracy should fill out the ranks of what is currently a reduced electoral democracy.

As Pierre Rosanvallon (2011: p. 122) has noted, election is not the same as representation; election is an "empirical convention" in the history of democracy, which is why he proposes "desacralizing it". The aim would be to desacralize the electorate without renouncing the principle of democratic self-government, although it might be better to speak of expanding democracy (representatively). This expansion would imply overcoming the mathematical vision of the people. 
There is no need to renounce the idea that the people are sovereign, but we must keep in mind that the identity of the people is continuously challenged by the requirements of inclusion. Democracy is a political system whose sovereign is not closed or identified forever, "in which the people will be said to be sovereign, of course, but whose identity will constantly be open to question" (Lefort, 1986: 303-304).

This is not an issue of eliminating anything, not elections, not representation, not electoral institutions, but of making them more complex and inclusive. If democracies have kept alive and in tension the difference between majority and totality, that tension today points toward including our contemporary neighbors, those who will inherit our present and the environment among those who are represented and those who decide.

\section{The Democracy of the Others}

Democracies have stopped limiting themselves to interactions with their own electorates. They must open up to foreign interests, examining the costs they impose on others when they adopt certain decisions. Globalization challenges constitutionalism and democracy, among other things because the "we" whose identity is defended and that is self-determined has lost its fixed reference to a stable framework of identification and management, such as the domain of the nation state or of a clearly delimited community. In the space of globalization, with porous and multiple identities, in the midst of complex interactions, where contagion and interdependency reign, when everything is contaminated and there is no protective space, the category of "us" is characterized by great indeterminacy. In a space of common goods or common evils, any delimitation between us and others that is too rigid is inappropriate. Of course, the voters should be delimited, but that does not imply that they should be closed in the name of popular sovereignty. We should think of ourselves in an open and even potentially universal fashion. At the same time, we must construct new systems of responsibility that are operative and reflect the complexity of an interdependent world.

1) Cross-border self-determination

Democracies barely have instruments to assure that "outside" identities and interests are taken into account in their decision-making processes. The legitimacy of cross-border institutions stems from the attempt to mitigate these failures, which constitutes a correction to the nation state, to overcome their shortsightedness and include the recognition of other people in their own political structures (Joerges \& Neyer, 1997). Self-determination today, under current conditions, means accepting the effects that the decisions of other nation states have on us to the extent that we have had the opportunity to make our interests heard in "their" decision-making processes and, inversely, to be ready to make other citizens the subject of our decisions. We have to work for a system of collective multi-level governance, in which national democracies open themselves 
to the concerns of foreigners.

A society is not sufficiently self-determined when it is only nationally self-determined. This failure makes some sense if we keep in mind the political conditions in which today's societies find themselves. The more determined that life is for citizens because of interdependence, the less their demands for self-determination are limited to the arena of the nation state. The rights and responsibilities of self-determination require us to abandon the "parochial focus" of political representation (Gutmann \& Thompson, 1996: p. 146). The open character of democracies would be betrayed if the deliberative community were always coextensive with the demos of formal procedures of decision-making, with national citizens or the electorate itself.

This is true to the extent that we can speak without exaggeration of a deficit of democratic legitimacy when a society cannot intervene in the decisions of others who condition it, but also when it prevents those others from intervening in its own decisions that condition them. In an increasingly interdependent world, the idea of "democracy in a single country" makes no sense, which does not mean that a deterministic logic makes democratic contagion inexorable or that the exportation of democracy is always just and effective. Formulating it instead in a negative fashion, we can see that when a democracy in one country is achieved at the cost of no democracy in another country with which it maintains a relationship of interdependency, harming its right to its own determination, that conditioning undermines the opening and inclusion that should characterize all democracies. Unlike the modern world of democratic states that do not need democratic environments-and those that could even benefit from a terrible external world or an antidemocratic enemy to maintain their own cohesion-in the current world, a democracy that does not promote-and we must strip this of any colonial echo-democracy beyond its own borders is unthinkable. It is a systemic, structural question, not a civilizing mission.

2) The cross-border construction of democracy

The "mutual opening up of democracies" (Nicolaïdis/Shaffer 2012) begins with the consideration that the subject that self-determines must be sufficiently indeterminate so as to include others in every case. Democratic indeterminacy must be open in order to allow some involvement in our decision-making processes by those who we understand to be concerned by our decisions, to the extent to which a relationship of interdependency is in fact established. It is a question of opening the door to the hybrid figure of "my aliens", in other words, those who are both "alien" and "mine" (Shaw, 2003).

The normative nucleus of representative democracy centers on the fact that representatives are required to report to those they represent-and only to them-because it was presumed there were no effects worth considering toward the "outside", that could not be sheltered by reasons of state or undervalued as a neutral externality. As the interaction between states and their mutual responsibilities increases, there is an increase in the number of parties before whom po- 
litical decisions must be justified to the extent to which they are significantly affected, since they can no longer be disqualified as mere externalities. The integration of a national political process in multilateral contexts expands the political audience before whom political decisions must be justified (Neyer, 2012: p. 69). That which is public-the realm of justification and decision-is not equivalent to that which is delimited by the state, but includes "everyone affected by a problem" (Dewey, 1988). The idea of cross-border self-determination presents precisely a conceptual framework to think how we should make decisions when they reach beyond the state framework; it references this additional level of governance that is necessary to give a structural pathway for those who are affected by the decisions of others or, inversely, to internalize the external effects of their own decisions.

Democracy implies a certain identity between those who decide and those who are affected by those decisions. Respecting this criterion means that the effects of the decisions of other nations are unacceptable if we have not had the opportunity to assert our affairs into "their" decision-making process and if we have not been prepared, reciprocally, to take other citizens into consideration in our decisions. We are all obligated to redefine our own interests by including the interests of our neighbors in them in some way, especially when we are connected with them not only by physical proximity or general interdependence, but by the institutional community, as is the case with the European Union. The promise of national democracy to promote self-government can only survive Europeanization if at this level of interdependency there is a demand for a justifying discourse that credits the systematic respect for the external effects of their decisions as something relevant for domestic decisions (Joerges \& Neyer, 1997).

The principle of taking everyone affected into account (Bohman, 1996; Dryzek, 2001; Gutmann \& Thompson, 2004) can be a rigorous obligation or an unrealizable lack of moderation, it can range from the mere requirement to inform to the strict obligation for co-deciding. In any case, what is important about this principle is that, defining the reach of the deliberative community by those affected and not by its formal members makes the space for political decision-making less formal and breaks its closure into constituted state frameworks. The principle of affectation challenges the institutional closing of communities that are thus decentralized, open and revisable in each case. It is clear that this then presents a problem of indeterminacy, but it prevents the closure of the community that privileges its members, the aristocracy of the belonging that tends to crystallize in an electorate that is incapable of taking any responsibility in relation to others.

Democracy is weakened when many of those affected by a decision have no say in decision-making, which happens in the space and time when decisions made within one country have a large impact in another or when they significantly affect future generations, whose interests should be anticipated in some way. The justification owed by representatives is not merely resolved in the heart 
of the electoral base, it cannot halt with their own immediate interests. Instead, it points toward a general obligation of justification that includes those affected by the decisions and their consequences. Although it is not always easy to demarcate this range, the obligation is potentially universal to the point that what must be justified is the reason we stop at a particular "us."

To the extent that interdependencies are increased, self-determination becomes more complex, both in space and time. We must move toward a cross-border self-determination of space in the same way we should point toward intergenerational self-determination as the normative horizon of time. Self-determination is a principle that is not simply articulated by a spatial or temporal delimitation. Making self-government more democratic today means making it more complex so it can include the interests of distant places and times with which we maintain conditioning relationships and, therefore, certain responsibilities of justice. Self-determination continues to be a basic principle and, without it, democracy would be inconceivable; the problem is that in a world where there is overlap and conditioning, it requires thinking with greater subtlety than when the subjects of those rights (peoples, generations, cultures) were more or less delimited units and could exercise their sovereignty in an isolated manner.

\section{Intergenerational Democracy}

Electoral democracies have a systematic bias in favor of the present, while they undervalue the future; in other words, they tend to place the interests of current voters above those of future voters, they care more about upcoming elections than upcoming generations. By privileging current voters, democratic institutions establish an unjust electoral asymmetry: current citizens have a right to vote that future citizens do not enjoy. Future generations have neither voice nor vote; they lack power when it comes to politics in which only current voters and their interests are represented. The fact that current politicians are not held accountable by future citizens has a decisive impact on their incentives when it comes to making decisions.

One of the principal challenges of our democracies, if they truly want to be inclusive, consists precisely in exploring the possibilities of correcting this bias and finding a way to institutionalize the consideration of future voters. Moving toward a type of intergenerational democracy would allow us to overcome the limitations of electoral democracy so we can achieve the same radicalization of democracy in the dimension of time that I have proposed in the dimension of space: completing cross-border self-determination with transgenerational self-determination.

1) The privilege of current voters

From a cultural point of view, within the logic of consumption, when it comes to the environment, but also through our democratic practices, we embody an imperialism that is no longer related to space but to time, an imperialism of the present that colonizes everything. There is a colonization of the future that con- 
sists of living at its expense and an imperialism of the present that absorbs the future and feeds off it parasitically. Bertman (1998) calls it "the power of the now", the present that is not invested in any other dimension of time. This present replaces the long term with the short term, duration with immediacy, permanence with transience, memory with sensation, vision with impulse.

One reason for this reduction in the scope of our attention stems from the fact that the units of time in representative democracies are structured by electoral cycles. The rules that confer power on governments do so for a predetermined period of time. Democratic competitions that determine winners and losers are generally held every four years. This elemental rhythm marks the tendency of political strategists to focus on the goal of not losing power or on achieving it. Democratic elections are a competition, but only for the approval of those who vote in the present, not for those who may do so in the future, even though they may be the ones who are most affected by our decisions. This limits the political playing field since it requires that problems be dealt with according to the legislature's temporal time frame. Problems are managed in such a way that they improve-or at least, do not decrease-the likelihood of governing in the next legislative session. Any problem that does not adapt to these circumstances is delayed or confronted only when there is no other alternative.

This attitude reduces public interest to the scale of voters' interests. It simplifies political power, reducing it to the power of the electors. Public interest is not merely the concrete will of the voters, but also an inter-temporal reality, the only thing that can justify long-term plans. The public interest is comprised of measures that are not meant to resolve but to shape: investments, structural agreements, large-scale projects in areas like education, infrastructures, pension plans, energy policies, government reform, etc. In order to offer these types of issues the attention they deserve, we need a different configuration of political willpower and a different temporal register so as to complement electoral rhythms.

Our fixation on the present leads us toward a more uncomfortable question: do we have more rights than our descendants? Is it fair to create a "temporal preference for those who are currently living"? Would this not be a temporal version of the privilege that some people want to establish in space, a type of time-based colonialism? In both cases, a complicity of "us" is established at the expense of a third party: in spatial exclusivism, the third party was the person from elsewhere, while in temporal imperialism, the person from later is the one who pays the price for our preference. This is precisely what happens when the temporal horizon is narrowed: a type of "coalition of the living" tends to be configured, constituting the present generation's true dominion over future generations. The surprise that Kant felt when he observed how previous generations work so arduously for later ones has now been reversed. The opposite seems to hold true today: by making present time absolute, we make future generations work involuntarily in our favor.

We enjoy a type of impunity in the temporal zone of the future where we can 
recklessly deplete other people's time or expropriate other people's future. We are "squatters" on future turf. The more we live for our present, the less capable we will be of understanding and respecting the "nows" of other people. When the consequences of actions are extended through space until they affect people on the other side of the world and through time until they condition the future of people near and far, then a good many ideas and practices require profound revision. Both spatial and temporal interconnectedness should be taken into thoughtful consideration: anything that implicitly conditions the future should be made transparent and the object of democratic processes. A broadening of our temporal horizon is one of our most basic moral and political imperatives. In summary, this means we can no longer think of the future as the garbage collector of the present, as an "unloading zone" (Kosselleck), a place where unresolved problems are sent so as to rid the present of them.

2) Principles and institutions for intergenerational self-determination

The realization that the destiny of various generations is as intermingled as the spaces of globalization calls into question our occupation of the future. If responsibility for the future has turned into an acute problem, it is because there has been an increase in the number of future scenarios we must keep in mind during present-day decision-making and planning sessions. This is a result of the lengthening of the causal chains that connect us in space and time. The processes of modernization create, among other things, growing reciprocal dependencies in space. On the temporal side of things, as we shall see in a moment, this leads to an expansion of the chronological dimensions of the future. In fact, our actions have so much influence over the future that "we have a moral obligation, as we are making our daily decisions, to consider the well-being of those who are not consulted even though they are going to be affected. We do not choose this obligation, but it is imposed upon us because of the incredible scope of the power we exercise daily. We act upon the things we have beside us, but without any extra effort, our actions also bring about changes at a distance" (Jonas, 1992: p. 128).

These facts have set in motion a whole new set of reflections about intergenerational justice (Gosseriess, 2004). Discriminations that are connected to age or generational condition (where one generation makes impositions upon another or lives at the other generation's expense) pose specific challenges to the course of justice. Most of the political decisions we adopt have an impact on future generations. For example, social service issues (health care, pensions, population shifts, unemployment insurance) need a broad temporal framework and a cognitive focus on possible future scenarios. Is it morally defensible to convey nuclear waste, a polluted environment, considerable public debt, or an unsustainable pension system onto future generations? We must weigh issues of justice when examining the things that get passed from one generation to another. These transfers include legacies and memories, but also expectations and possibilities that are handed over to future generations, in terms of physical, environmental, 
human, technological, and institutional capital. We should shift from property that is private, generational, and grounded in time to an intergenerational, collectivization of time, especially the future.

Generational interdependence demands a new type of social contract. In accordance with the new realities of spatial and temporal interconnectedness, it no longer makes sense to understand the social contract in an exclusivist sense. In other words, it cannot be limited to one specific community or to those who are currently alive. The model of social contract that only regulates obligations between contemporaries must be expanded to include future subjects with whom we find ourselves in complete asymmetry. Questions of intergenerational justice are not resolved with a sense of reciprocity, but with an ethics of transmission. The fact that the common good is transgenerational and universal relativizes the present and poses a limit to concurrent ethics founded on the basis of mere reciprocity. There is a basic inequality between the present and the future that does not exist among contemporaries. If we only consider the meaning our actions have on our present-day interests, we will not be capable of understanding the ways we influence the future and the extent to which those repercussions require us to provide a political and ethical response. If we mine the consequences of this interdependency, we will have to consider what Hans Jonas (1984) has called a nonreciprocity of duties to the future. Care, consideration, concern, and responsibility extend beyond the realm of our closest connections. Preuss has given this imperative a Kantian formulation: "Do not limit the freedom of future generations beyond what you would be willing to allow previous generations to limit you" (1984: 227).

How can we fulfill these principles in democratic institutions? On the constitutional level, the first thing we can confirm is that few of them represent or adequately protect the interests of future generations. In general, there are no recognized rights for those who will live in the future, nor are there previsions for those citizens to be represented in legislative assemblies or in executive institutions. While constitutions protect certain minorities in different ways, there are no equivalent previsions for future generations, even though this may include many people and their interests may be affected by our decisions. All the constitutional checks and balances were meant to protect us against the tyranny of the majority; today we need procedures to protect future generations from the tyranny of the present (Tremmel, 2015) or according to a principle of "intergenerational neutrality" (Coleman, 2012) so that benefits and responsibilities are distributed between generations in such a way to ensure equality across time.

Many of the explicit references to future generations are in the preambles to constitutions - as is the case with the Charter of Fundamental Rights of the European Union (2000), recognized in the Treaty of Lisbon (2008) - and they are generally of a non-binding nature, as mere aspirations. Some of them address this issue when they talk about protecting the environment or through the concept of legacy, but they do not allude to the rights of future generations as such 
(Göpel \& Arhelger, 2010: 5). They provide some orientation for policy but have limited practical or judicial value. Moreover, even if constitutions incorporate certain values and principles oriented toward the future, this does not guarantee that representatives and governments will give them sufficient weight in practice (Tremmel, 2006). The discrepancy on this point between constitutional principles and political practices tends to be considerable.

The exclusion or inclusion of future generations does not only depend on the text of the constitution but also the way changes to it are planned. As a matter of principle, the easier it is to modify, the less sovereign those who approved it and the more sovereign those who will have the possibility of modifying it. The conflict between the defenders of electoral sovereignty and its critics cannot be easily resolved. In any case, it would be good to design constitutions in such a way that the inter-temporal balance would be susceptible to periodic revision. It is important for constitutional reforms to be sufficiently restrictive so as to discourage frequent changes but not to the extent that it is practically impossible for future generations to carry out the modifications that they judge necessary to respond to changing needs and challenges.

Even if future citizens do not vote, there are certain modifications of the electoral system that can be made to improve their inclusion in these processes to an extent. Debates about whether a proportional or majority system is better, the voting age, compulsory voting, rules for campaign finance ... can reveal arguments to support different objectives, including the question of what is needed to make the interests of future generations more present. For example: everything that has to do with the duration and stability of governments-requirements for investiture and censorship-hastens or delays the involvement of new generations in the change of parliaments and government.

It is true that the interests of people at different ages are distinct and that one could normally presume that young people are more interested in the long-term perspective than older people (van Parijs, 1998: 297). The first group will have more interest in educational policies, the environment and fiscal prudence, while the second group will be more concerned about pensions. Given the aging of the population in advanced democracies and the fact that older people have increasing influence in the voting booth, political decisions will tend to favor older people over younger people, as well as short-term over long-term interests. There is little empirical evidence, however, that young people are more sensitive toward the necessities of future generations or more altruistic than older people or that lowering the voting age means better anticipating future interests (Chan \& Clayton, 2006; Freund \& Blanchard-Fields, 2014). On the basis of the rate of intergenerational justice that was developed from a series of measurements, demographic structure does not seem to affect the way policies favor certain age groups (Vanhuysse, 2013). Sweden, for example, has one of the oldest populations in the OECD, but its policies reveal very little bias toward older people. Poland, on the other hand, has a comparatively much younger population and 
policies that favor older people. There is no reason to suppose that empowering the younger generation will help impede future disasters and improve long-term governance. The solution to the problem of how to serve long-term interests and future generations should be more deliberative than representative and participatory.

3) Deliberating about mute interests

How can we assert "mute interests" (Goodin, 2003: 209)? It is a question of incorporating those who cannot participate in democratic deliberations, who cannot speak for themselves, but who have as much right to be protected as the humans who are part of the current electorate. It is not possible to make distant or future people present, nor can we find a way to make nature available; we can only place ourselves imaginatively in their place and, in this way, deliberate about their interests. Who can speak in the name of future citizens and with what legitimacy? Future generations cannot authorize anyone to act in their name, which means we will inevitably be acting amid suppositions about what their future interests may be. Their identification and defense cannot be carried out except hypothetically or virtually and through controversy among current citizens.

It is not very clear what it means to speak in the name of future generations, how to measure the effectiveness of what those who assume these functions carry out and the ways in which they can account for their decisions, when those whose future interests are in play cannot express their opinions at this time (Smith, 2014). How, then, can we measure all this? Generational justice, understood as the principle of representing the interests of future generations, is one of our most highly discussed political concepts. All the models of overlapping generations or of generational accounting have a strong hypothetical dimension. Generational predictions must be legitimized individually because no one wields the unlimited power of representing the entire future or of rightfully speaking in the future's name. The controversial character of these predictions is also aggravated by the fact that the empirical desires of the supposed beneficiaries cannot be guaranteed, since there are no valid elections or opinion polls to reflect the views of future beings. In spaces of complexity, just as when we have to anticipate the interests of other people, of future generations or of nature, when physical conversation is not possible, there is no solution except to practice an imaginative-reflective deliberation (Goodin, 2003), hypothetically internalizing the voices that cannot be expressed (or only to a very limited extent).

We cannot be certain what those who come later will want, and for that reason, we must arbitrate procedures to give the future the freedom to make its own choices. In this context, Jefferson (1984) even questioned whether all laws would need to be passed anew according to the cycle of generations. In a letter from 1813 , he states that we can consider every generation a separate nation with the right to make binding decisions but lacking the power to force upcoming generations to abide by them, just as we are banned from forcing inhabitants of other 
countries to do so. Contracts die with the people who signed them (1984: 1280). Nowadays, the ethical philosopher Peter Singer seems to defend a similar position when he wonders, for example, whether our descendants will appreciate the wilderness or whether they might not be "happier sitting in air-conditioned shopping malls, playing computer games more sophisticated than any we can imagine" $(2000,92)$. Both are, in my judgment, abstract approaches, since they do not take into sufficient account the overlap and interaction between generations or the impossibility of strictly separating them. Although it is clear that there should be clauses and procedures for revision, any question about justice between generations must also take into account the fact that the generations interact; history is not a succession of discontinuities. There are connections between generations, such as duties of memory or the legitimacy of shaping the collective future, without which the very idea of a society would be incomprehensible.

We do not have complete certainty about what will be necessary so that future generations will be able to flourish fully, and what they need will certainly evolve, but that does not prevent us from presuming that they have the right to have the greatest possible number of options at their disposal and that they should not have to take on more responsibilities than is reasonable. It is all very well that we defend their right to make their own decisions, but we cannot forget that their free decision depends on the existence of certain social conditions and common goods the assurance of which depends on our current decisions (Raz, 1986: 250). Many of our decisions when it comes to sustainability, taxation, risk mitigation, catastrophe prevention, protection of democratic institutions, the preservation of cultural treasures, the provision of goods and public services can be adopted reflexively with the objective of not restricting future options and minimizing future damages.

It is not so much a question of freeing future generations as the need to legitimize the way we inevitably shape the future. We need to configure what is to come in accordance with guidelines for justice that goes beyond our current interests. We cannot allow ourselves the comfort of using respect for future decisions as our only guideline for action, because certain decisions are required of us in order to afford coming generations any freedom of choice. The paradox of intergenerational respect could be formulated in this way: we must make certain decisions now so that they have the freedom to choose later on.

\section{An Ecological Democracy}

When the ecological question appears in our democracies' political agendas, its first effect is the identification of a series of human duties when it comes to the natural world. The debates intensify to the point of constituting some rights of animals that humans should respect (Singer, 1975; Nussbaum \& Sunstein, 2004; Donaldson \& Kymlicka, 2011). Without addressing this specific debate, I would like to add the perspective about the extent to which this issue modifies the very 
nature of democracy and questions the universality of our procedures of representation. In modernity, democracy is conceived as a collection of institutions that have allowed people to abandon the natural world. The entirety of modern politics has been an attempt to escape the "state of nature", which is not a simple metaphor. At the point at which this contrast is overcome, once we begin to see ourselves as part of the natural world, to recover our own ecological nature, the question that inevitably presents itself is the ways in which democratic representation becomes receptive to the recognition of nature as a political subject. It is not a question of having animals vote or setting aside seats for them in parliament, but of having nature be represented in some way in our democracies. A truly inclusive democracy does not necessarily imply that the rights of animals are recognized or that animals are granted a place in our systems of representation; what it means is replacing the modern paradigm that sets natural brutality in contrast with civilization and culture, substituting a new understanding of our political systems as insertions into a natural environment that does not correspond with spatial limitations or with the logic of our electoral democracies.

We are not only confronting a problem of how to manage certain public goods, but we are in the midst of a profound democratic deficit, a true exclusion. If nature has to be recognized, represented and included as a political subject, that means that contamination or the abusive exploitation of nature is not merely failures of our productive system; they also constitute a true democratic failure and reveal that our political systems, understood as completely distant from the natural environment, have established a sovereign subject that excludes other non-human subjects and nature itself, in other words, they are not fully democratic.

This perspective questions the sovereignty of voters recognized as such. If the objective is to integrate non-human groups into society, to undo the privilege of our species (Donaldson \& Kymlicka, 2011), then we must first question the privilege of voters recognized as such until now. The environmental question tacitly introduces new constituencies into the political agenda, thus problematizing the way representative democracies currently work. Environmental questions challenge the idea of an electoral democracy in various senses, fundamentally because they put in play goods and interests that transcend the national-electoral delimitation and because these issues cannot be adequately managed by the institutions arising from that electoral logic. Any deficit in ecological matters is, in the end, a democratic deficit and will force us to consider institutional alternatives. Politics must be less anthropocentric and more biocentric. We need to move from the paradigm of national culture to one of a cross-border nature.

1) Cross-border contamination

Let us begin with the space-time challenge implied by the fact that ecological questions are decoupled from political delimitations. Pollution is a cross-border traveler. Large ecological issues have been almost completely dissociated from the framework defined by the states (and their corresponding systems of repre- 
sentation and decision-making) along three dimensions: through the creation of the problem (who or what type of conduct causes a particular problem), the impact of the problem (who suffers what type of negative effects) and the solution to the problem (who is responsible for resolving it and in what way) (Mayntz, 2009: 74). The origins, impacts and solutions to certain problems (problem generation, problem impact, problem coping) do not correspond to the limits of the traditional unit represented by state-organized societies. All of that defines a framework of interdependence or mutual dependence that implies shared vulnerability and demands that we reconsider who we are ultimately, whether our political subjectivity can be contained in an electoral census.

The fact that environmental problems are not contained within our delimited spaces is particularly perceptible in the case of climate change, but not only there. There is no logical congruence between natural spaces (certain geographic regions, watersheds, spaces affected by the depletion of the ozone layer, meteorological phenomena, cross-border areas that have unnatural divisions even when they share a natural space and others that are conjoined in spite the heterogeneity of their natural settings ...) and the borders between states with their electoral censuses. The political space and the ecological or natural space barely coincide, and political delimitations are not retaining walls that can limit the effects of our pollution or protect us from the pollution of other people. The effects are, at times, not even felt nearby, but produce alterations in remote regions. Those who are most responsible for environmental degradation are not necessarily the ones who most suffer from it or who have the ability to resolve it. We are all both receivers and exporters of ecological damages. All our national institutions of representation and accountability end up being true anachronisms in a world that is defined by great mobility, spill-over effects, openness and particularly by a lack of protection by state agencies.

There are also incongruities from the temporal point of view. In the first place, because the electoral cycle does not correspond with ecological time. The disconnect between those who decide and those who suffer also has a temporal dimension. There is imbalance in the creation of a problem (it takes less time to consume natural resources than is needed to replace those resources) and another imbalance which refers to the fact that those who have caused the problem and those who suffer or will suffer from it do not exist at the same time. Voters approve certain decisions whose ecological impact will not affect them but future voters who do not currently exist (or do not have the demographic weight of adults in an elderly society for whom the distant future does not matter very much). As if that were not enough, the time required for intervention in these issues does not match electoral time periods, accountability sometimes refers to authorities who are no longer such ... These and other similar incongruities leave us with a desynchronization that the founding fathers of modern democracy did not have the opportunity to observe.

Environmental problems involve a complex formation of spatial-temporal 
gradations, they are problems at a distance, discontinuous in time and boundless in space, with latency periods and an impact that is distant or transgenerational and difficult to identify. In short, the limits of states and the delimitations of voters stem from various historical contingencies, in the expansion of power, colonial history, ancient tribal and religious divisions, certain agreements from the past, but the limitations on environmental protection are fundamentally ecological. I am not saying that voters should be made to coincide with those natural spaces, but if we want to address the ecological question, we have no choice but to reconsider that autarchy of political delimitations and open them to a dimension that is global, cross-border and cooperative.

2) The alleged incompatibility between democracy and ecology

Electoral logic hardly presents incentives to encourage those who vote or are elected for a brief period of time and in a concrete space to concern themselves with issues affecting another time and another space, such as ecological questions, most of which will affect other people more. Who can demand sacrifices now to avoid distant or future damages? What does accountability look like when it comes to our ancestors? What politician is capable of giving more weight to the rights of those who are not yet present than to his or her constituents?

There seems to be incongruity between democratic procedures (especially the ones that have to do with elections) andenvironmental protection policies, as if democracy and nature are unable to get along. Democracy would be an impediment for environmental policies and the fight against climate change because of the relationship between democracy and time: I am referring to that concern for the fact that the institutions of liberty, such as politics or the free market, cannot resolve society's problems and risks when they reside in the future (beyond the electoral cycle or the simple aggregation of interests).

This is the reason that there has been a recent proliferation of technical institutions, such as agencies specialized in addressing these issues, and that there are even direct appeals for authoritarian solutions. In both cases, in technical depoliticization and in authoritarian depoliticization, the starting point is a suspicion that the commitments required by environmental policies would have to be taken out of the "political business cycle" in some way.

The technical solution is justified by the existence of a "systemic short-circuit of democracy in an ecological context" (Bourg \& Whiteside, 2010). This short-circuit consists, in the first place, in being an issue whose complexity is only identifiable by the experts, but that in a democracy is ultimately decided by everyone (particularly through elections). The agencies offer a solution to the problem presented by the contradiction between the short-term temporal perspective that characterizes politics and the necessity for long-term solutions in many areas, especially those related to ecological risks and environmental protection. An institution that was subjected to electoral ratification and its time-frames would be in no condition to take a series of steps that could only be justified by a 
long-term perspective, which is completely missing from our electoral democracies. Environmental commitments-which have to do with interests that are by definition barely present in our decision-making procedures-require some type of justification that does not depend on the will of the voters who actually exist. One of our biggest problems is how to give weight to that which we share and to the future when governments have no incentive to take into consideration the negative externalities that their decisions produce in distant places and times.

It is not illogical that, in the face of great environmental risks, we make an appeal to exceptional circumstances, calling for the technical depoliticization of those issues and even for authoritarian forms of government (Shearman \& Smith, 2007; Lovelock, 2009), something that has been called "environmental authoritarianism" (Beeson, 2010). There are those who hope for this type of solution from an authority figure who is not simply an independent actor, but a strongman, and they even talk openly about an authoritarian solution for environmental problems. But the truth of the matter is that the countries that have done the most good for the environment-even if they have also been the ones who have most damaged it-are representative democracies. Non-democratic regimes (or those that practice this authoritarian modernization) tend to do worse at managing the inter-temporal trade-offs and environmental sustainability than the democracies, even though they do not suffer from electoral pressures (Burnell, 2012; Congleton, 1992).

3) A democratic politics of nature

But there is a more fundamental reason to believe that democracy and ecology are not incompatible. What are we talking about when we talk about nature? Nature and the amount of protection it receives are not objective, indisputable issues. There are, for example, immediate reservations when it comes to defending the depoliticization of climate change because, even though there is broad consensus about the facts, that does not mean there is agreement about policies. There are many different natures, and the purpose of democracy is precisely to resolve the disagreement about the things we need to manage. The fact that we need to respect the environment does not negate the possibility of making a decision, for example, between different levels of ecological risk, which means we already have a conflict between different voters who are similarly affected by the same problem. Like all policies, the ones that refer to the protection of nature have their costs. Sustainability involves the redistribution of costs and benefits, which is, in this case, an issue of particular complexity, which is why it is not at all surprising that there are certain disagreements surrounding it. Expert opinion does not necessarily align, even when it comes to questions about which we trusted the experts' objectivity.

It is also unsurprising, and for the same reason, that the environmental cause has taken on very diverse formats, some more democratizing and others authoritarian: it has been a shout-out for help from the experts, but also a demand for greater participation or better legal regulation. The green movement has even 
acquired forms of intolerant nativism; it has had moments of profound distrust toward science and technology while at other times it has decisively promoted them. This ecological pluralism is a sign that the call to nature does not bring about a definitive end to our controversies and that, therefore, it is not in principle at odds with democracy, which is the political regime that assumes responsibility for controversies.

Arguments in favor of the exclusively technological-authoritarian treatment of these issues are too pessimistic when it comes to democracy's capacity to manage ecological risks and too optimistic regarding the experts' planning abilities (Stehr, 2016: 202). In areas where scientific statements are not indisputable and there are still opposing interests to consider, democracy is inevitable and necessary. Only democracy is ultimately capable of handling with legitimacy the uncertainties, the pluralism of values and interests that are put into play whenever we confront serious environmental impacts.

Environmental protections demand a strengthening, not weakening, of democracy. It is true that ecological problems can sometimes be better handled by protecting them from popular pressure, but also by opening their management up to criticism and to citizen participation. Environmental policies and those combating climate change should be compatible with democracy; if not, in addition to confronting a threat against our physical surroundings, we would also be in need of defending our civilized way of life (Baber \& Barlett, 2005; Dryzek \& Stevenson, 2011).

\section{References}

Achen, C. H., \& Bartels, L. (2016). Democracy for Realists: Why Elections Do Not Produce Responsive Government. Princeton, NJ: Princeton University Press. https://doi.org/10.1515/9781400882731

Baber, W. F., \& Barlett, R. (2005). Deliberative Environmental Politics: Democracy and Ecological Rationality. Cambridge, MA: MIT Press.

Beeson, M. (2010). The Coming of Environmental Authoritarianism. Environmental Politics, 19, 276-264. https://doi.org/10.1080/09644010903576918

Bertman, S. (1998). Hyperculture: The Human Cost of Speed. Westport, CT: Praeger.

Bohman, J. (1996). Republican Cosmopolitanism. The Journal of Political Philosophy, 12, 336-352. https://doi.org/10.1111/j.1467-9760.2004.00203.x

Bourg, D., \& Whiteside, K. (2010). Vers une démocratie écologique. Le citoyen, le savant et le politique. Paris: Seuil.

Brennan, J. (2016). Against Democracy. Princeton, NJ: Princeton University Press. https://doi.org/10.1515/9781400882939

Burnell, P. (2012). Democracy, Democratization and Climate Change: Complex Relationships. Democratization, 19, 813-842. https://doi.org/10.1080/13510347.2012.709684

Chan, W., \& Clayton, M. (2006). Should the Voting Age Be Lowered to Sixteen? Normative and Empirical Considerations. Political Theory, 54, 533-558. https://doi.org/10.1111/j.1467-9248.2006.00620.x

Coleman, A. (2012). Intergenerational Transfers and Public Policy. Wellington: New Zealand Treasury. 
Colomer, J. (2001). Political Institutions: Democracy and Social Choice. Oxford: Oxford University Press. https://doi.org/10.1093/019924183X.001.0001

Congleton, R. (1992). Political Institutions and Pollution Control. Review of Economics and Statistics, 74, 412-421. https://doi.org/10.2307/2109485

Dewey, J. (1988) The Later Works, 1925-1953. In J. A. Boydston (Ed.), The Public and Its Problems (Vol. 2). Carbondale and Edwardsville, IL: Southern Illinois University Press.

Donaldson, S., \& Kymlicka, W. (2011). Zoopolis: A Political Theory of Animal Rights. Oxford: Oxford University Press.

Dryzek, J. (2001). Legitimacy and Economy in Deliberative Democracy. Political Theory, 29, 651-669. https://doi.org/10.1177/0090591701029005003

Dryzek, J., \& Stevenson, H. (2011). Global Democracy and Earth System Governance. Ecological Economics, 70, 1856-1874. https://doi.org/10.1016/j.ecolecon.2011.01.021

Freund, A., \& Blanchard-Fields, F. (2014). Age-Related Differences in Altruism across Adulthood: Making Personal Financial Gain versus Contributing to the Public Good. Development Psychology, 50, 1125-1136. https://doi.org/10.1037/a0034491

Goodin, R. (2003). Reflective Democracy. Oxford: Oxford University Press. https://doi.org/10.1093/0199256179.001.0001

Göpel, M., \& Arhelger, M. (2010). How to Protect Future Generations' Rights in European Governance. Intergenerational Justice Review, 10, 3-9.

Gosseriess, A. (2004). Penserlajustice entre les generations. Paris: Aubier.

Gutmann, A., \& Thompson, D. (1996). Democracy and Disagreement. Why Moral Conflict Cannot Be Avoided in Politics, and What Should Be Done about It. Cambridge, MA: Harvard University Press.

Gutmann, A., \& Thompson, D. (2004). Why Deliberative Democracy. Princeton, NJ: Princeton University Press. https://doi.org/10.1515/9781400826339

Jefferson, T. (1984). Writings. Edited by Merrill D. Peterson, New York: The Library of America.

Joerges, C., \& Neyer, J. (1997). From Intergovernmental Bargaining to Deliberative Political Process: The Constitutionalisation of Comitology. European Law Journal, 3, 273-299. https://doi.org/10.1111/1468-0386.00031

Jonas, H. (1984). The Imperative of Responsibility: In Search of an Ethics for the Technological Age. Chicago, IL: University of Chicago Press.

Jonas, H. (1992). Philosophische Untersuchungen und metaphysische Vermutungen. Frankfurt: Inser.

Lefort, C. (1986). The Political Forms of Modern Society. Bureaucracy, Democracy, Totalitarianism. Edited by J. B. Thompson, Cambridge, MA: MIT Press.

Lovelock, J. (2009). The Vanishing Face of Gaia: A Final Warning. New York: Basic Books.

Mayntz, R. (2009). Über Governance. Institutionen und Prozesse politischer Regelung. Frankfurt: Campus.

Neyer, J. (2012). The Justification of Europe. A Political Theory of Supranational Integration. Oxford: Oxford University Press. https://doi.org/10.1093/acprof:oso/9780199641246.001.0001

Nicolaïdis, K./Shaffer, G. (2012) Transnational Mutual Recognition Regimes: Governance without Global Government. Michigan Review of International Law, 68, 267-322. https://doi.org/10.1093/acprof:oso/9780199588770.003.0010

Norris, P. (2015). Why Elections Fail. Cambridge: Cambridge University Press. 
https://doi.org/10.1017/CBO9781107280908

Nussbaum, M., \& Sunstein, C. (Eds.) (2004). Animal Rights. Oxford: Oxford University Press.

Raz, J. (1986). The Morality of Freedom. Oxford: Oxford University Press.

Rosanvallon, P. (2011). The Metamorphoses of Democratic Legitimacy: Impartiality, Reflexivity, Proximity. Constellations, 18, 114-123.

https://doi.org/10.1111/j.1467-8675.2011.00631.x

Shaw, J. (2003). Sovereignty and the Boundaries of the Polity. In N. Walker (Ed.), Sovereignty in Transition. Essays in European Law (pp. 461-500). Oxford: Hart.

Shearman, D., \& Smith, J. W. (2007). The Climate Change Challenge and the Failure of Democracy. Westport, CT: Praeger.

Singer, P. (1975). Animal Liberation. New York: Harper Collins.

Smith, G. (2014). (Not) Dealing with Climate Change: Democracy, Institutional Design and the Long-Term. In Paper Prepared for Political Studies Association Annual International Conference, Manchester.

Smith, R. M. (2003). Stories of Peoplehood. Cambridge: Cambridge University Press. https://doi.org/10.1017/CBO9780511490347

Stehr, N. (2016). Information, Power, and Democracy. Liberty Is a Daughter of Knowledge. Cambridge: Cambridge University Press.

https://doi.org/10.1017/CBO9781316343159

Tremmel, J. (2006). Establishing Intergenerational Justice in National Constitutions. In J. Tremmel (Ed.), Handbook of Intergenerational Justice. Chetelham: Edward Elgar. https://doi.org/10.4337/9781847201850.00019

Tremmel, J. (2015). Parliaments and Future Generations-The Four-Power-Model. In D. Birnacher, \& M. Thorseth (Eds.), The Politics of Sustainability: Philosophical Perspectives. London: Routledge.

van Parijs, P. (1998). The Disenfranchisement of the Elderly, and Other Attempts to Secure Intergenerational Justice. Philosophy and Public Affairs, 27, 292-333. https://doi.org/10.1111/j.1088-4963.1998.tb00072.x

van Reybroucke, D. (2016). Against Elections. The Case for Democracy. London: Bodley Head.

Vanhuysse, P. (2013). International Justice in Aging Societies: A Cross-National Comparison of 29 OECD Countries. Gütersloh: Bertelsmann Stiftung. 